\title{
On the Theoretical Framework of Autonomous Learning
}

\author{
An Qi \\ Department of Foreign Languages Harbin University of Commerce Harbin, Heilongjiang, China
}

\begin{abstract}
The present research presents an overview of the definitions of two basic concepts in autonomous learning: learner autonomy, teacher autonomy. Based on these definitions, taking the Chinese context into consideration, this research attempts to redefine these concepts respectively. The present research is mainly concerned with the relevant theoretical framework of learner autonomy, namely cognitive learning theories, humanistic psychology, and constructivist theories of learning, and holds that developing learners' autonomous learning ability is very necessary to foreign language teaching reform in China. Several enlightenments are made in the end.
\end{abstract}

Index Terms: Theoretical frramework; autonomous learning; definitions

(C) 2012 Published by MECS Publisher. Selection and/or peer review under responsibility of the International Conference on E-Business System and Education Technology

\section{Introduction}

As more and more researchers investigate learner autonomy, they come to realize that teachers, during the process of the development of learner autonomy, play a very important role, and to some extent, can even determine whether learner autonomy can be realized. The roles that teachers play in the development of learner autonomy also draw researchers' attention in China. Against this background, the present researcher studies on the definitions of learner autonomy and teacher autonomy and theoretical framwork of autonomous learning in order to shed light on the study of the roles of teacher autonomy in the development of learner autonomy.

\section{TWO DEFINITIONS}

\section{A. Definitions of Learner Autonomy}

Holec (1981: 3)[1] defines autonomy as "the ability to take charge of one's own learning." He further explains: "To take charge of one's own learning is to have, and to hold, the responsibility for all the decisions concerning all aspects of this learning." Holec's influence on the study of learner autonomy has been so strong that many definitions of learner autonomy have subsequently been provided in the literature. Researchers such as Little (1990)[2], Kenny (1993)[3], Benson (2001)[4], Dickinson (1987)[5], Dam, L. (1990)[6], Gardner \&

* Corresponding author.

E-mail address: sharon0657@hotmail.com 
Miller (1996)[7] define learner autonomy from various perspectives---from "the learner's psychological relation to the process of learning" to "the capacity to take control of one's own learning", from "a recognition of the rights of learners within educational systems" to "the situation in which the learner is totally responsible for all of the decisions concerned with his learning and the implementation of those decisions.".

Developed from previous studies and deep reflections, these definitions have laid a solid foundation for the development of learner autonomy. From these definitions we can see that their concern is not so much whether learners learn, but whether learning practice is controlled by learners themselves in certain learning situation and whether learners have 'right' and 'freedom' in learning. To them, autonomous learners take responsibility for their own learning activities, set their goals, select learning materials, monitor and assess their own learning practice and finally evaluate the effects and effectiveness of their learning. In China, study on autonomous learning began in the early 1990s and, unfortunately, literature related to definitions of learner autonomy is rather slim. According to Xu Jinfen (2007: 11)[8], so far as Chinese learners are concerned, autonomous English language learning capacity involves five aspects: 1) understanding teaching objectives and requirements; 2) setting goals and making a plan for one's studies; 3) employing learning strategies effectively; 4) monitoring the effect of one's learning strategies; 5) monitoring and evaluating the English language learning process.

The above definitions and explanations, however, fail to provide detailed or concrete guidance concerning how to achieve the autonomous learning situations mentioned in those definitions. Based on the definitions and discussions on learner autonomy abroad and in China, taking Chinese College English learners into consideration, the present research defines learner autonomy as follows. Learner autonomy is: 1) the capacity to be responsible for one's own learning process, which includes the capacity to be clear about teaching objectives and one's own goals, 2) self-discipline in the process of learning, 3) the development of appropriate learning strategies and optimal utilization of English language information. In this definition, the capacity for dealing with English language information is noteworthy. It is even safe to say that no learner autonomy can be possible unless college English learners develop the ability to deal with copious information, print-based information as well as the sheer abundance of Internet-based information. The amount of information one obtains, to some extent, determines the effectiveness of the learning practice. Therefore, the capacity to deal with information should be considered in fostering learner autonomy.

\section{B. Definitions of Teacher Autonomy}

Compared with learner autonomy, the term 'teacher autonomy' is more complicated. Many researchers define it in different ways. Tort-Moloney (1997: 51)[9]defines the autonomous teacher as "one who is aware of why, when, where and how pedagogical skills can be acquired in the self-conscious awareness of teaching practice itself". Little (1995:179)[10] believes that teachers may be "autonomous in the sense of having a strong sense of personal responsibility for their teaching, exercising via continuous reflection and analysis... affective and cognitive control of the teaching processes". Similarly, Lamb (2000)[11] regards teacher autonomy as critical reflection, implying a gradual professional development. Thavenius (1999:160)[12] argues that teacher autonomy refers to the teacher's ability and willingness to help learners take responsibility for their own learning. McGrath (2000:102)[13] perceives that there are two dimensions of teacher autonomy: 1) self-directed professional development and professional action; and 2) the exercise of professional freedom. Smith (2000)[14] has developed McGrath's dimensions of teacher autonomy, and introduced the concept of teacher-learner autonomy, defining 'teacher autonomy' as "the teacher's autonomy as a learner".

As is mentioned above, the term 'teacher autonomy' is multidimensional and may therefore refer to many different aspects. Therefore, it is essential to study the term on a context basis. However, few attempts have been made to clarify the meaning (or meanings) of the term 'teacher autonomy' contextually so far. So far, Chinese scholars such as Tan Hong (2001)[15], Huang Jing (2007)[16], have done studies on teacher autonomy in foreign language education in China, and argue that teachers should play roles such as 'friend', 'expert', 'coach', 'puzzle-solver', etc. But these studies discuss teacher autonomy from the orientation of teachers' role, consequently lacking consideration of the relationships between teacher autonomy and learner autonomy.

There is a need, therefore, for English teachers to clearly know which dimensions of teacher autonomy are appropriate to promote in the Chinese educational context. Considering Chinese English language teaching, 
this research defines teacher autonomy as follows:1) flexibility to cope with both external and internal constraints for the benefit of teaching and learning, 2) professional ambitions to exert one's maximum potential, 3) realization to develop learner autonomy to help students achieve lifelong learning. According to this statement, teachers should take an active and critical attitude toward both national and local educational reforms, have a lifelong learning consciousness, consider the development of learner autonomy as their responsibility, and integrate professional development into teaching practice.

\section{THEORETICAL FRAMEWORK OF AUTONOMOUS LEARNING AND THE ENLIGHTENMENTS}

Under the influence of educational theories like cognitive learning theories, humanistic psychology, constructivist theories of learning, autonomy has gained momentum in modern society.

\section{A. Cognitive Learning Theories}

Philosophers such as Rousseau and Dewey put forward ideas that knowing and thinking develop with experience. Rousseau believes that learners should be responsible for their own actions and learn by enjoying or suffering the consequences. Rousseau's emphasis on the learner's responsibility for learning is a key idea of learner autonomy. In this sense, Rousseau's philosophy of learning serves as one theoretical base for learner autonomy. A later influence is Dewey. Dewey's major contribution to the idea of autonomy lies primarily in the aspects of the relationship between education and social participation, of education as problem solving, and of classroom organization. In addition to Rousseau and Dewey's ideas on experience, meaningful learning is another element in cognitive psychology. Dickinson (1995:14)[17] writes "there is convincing evidence that people who take the initiative in learning learn more things and learn better than people who sit at the feet of teachers, passively waiting to be taught... They enter into learning more purposefully and with greater motivation.", highlighting that if learning is not perceived by a learner to be meaningful, it is less likely to be incorporated into internal schemes. Cognitive psychology also makes a distinction between field dependence and field independence. The study of learning styles strengthens the definition of learner autonomy that incorporates learners' responsibility for their own learning. By definition, different ways of learning indicate various learning styles. Part of developing learner autonomy, then, involves acknowledging and respecting various learning styles. Some other important elements in learner autonomy are metacognition, learning attitude and motivation, and learning strategies. No learning is exercised in isolation. Metacognition is a cognitive process in which an individual can take conscious control of learning. Learning strategies include three types: cognitive strategies, metacognitive strategies, and social and affective strategies. According to Ellis (1994)[18], cognitive strategies include those that enhance storage, retrieval and compensation. Metacognitive strategies entail planning, monitoring and evaluation. Social and affective strategies help learners learn through interaction with others by regulating their emotions, motivations, and attitudes. It is based on these elements in cognitive psychology that the definitions of learner autonomy and teacher autonomy have been developed.

\section{B. Humanistic Psychology}

Humanistic psychology is a holistic approach, which considers much of human being as a whole rather than as combined parts and places the individual's inner world at the core of all human development. Among researchers who have influenced and pushed the development of humanistic psychology, Abraham Maslow and Carl Rogers are the most influential. Maslow develops a triangular model, known as the hierarchy of needs, which describes human needs that are universal in human beings regardless of race or culture. Carl Rogers' major contribution lies in his reconceptualization of the role of the teacher. His notion of teacher as a facilitator is central to classroom-based approaches to autonomy in language learning (Benson, 2001:33) [4]. The optimal relationship in teaching is therefore one in which the teacher adopts a non-judgmental, facilitating role in helping the learner achieve self-actualization and intervenes as little as possible in the natural development of the learner (Benson, 2001:32)[4]. To put it simply, humanistic psychology believes that human beings should 
develop to their full potential.

The central idea of humanistic psychology lies in the five basic principles of humanistic education: 1) Learners will be motivated to learn material if they have desire to learn and are able to choose it themselves. 2) Education should strive to arouse learners' interest in learning and provide guideline for learners concerning how they can learn on their own. 3) Humanistic educators believe that self-evaluation is a more meaningful assessment than grades, and they also oppose the use of tests because it encourages memorization and does not accurately convey what a learner may know. 4) Feelings and knowledge are given equal importance. 5) Learning is easier and more meaningful when students are able to feel secure in a non-threatening environment.

Although humanistic psychology has tremendous impact on language learning and teaching, especially in its ever increasing recognition of learner autonomy, the effects of humanistic education are vague. Humanistic psychology attaches much importance to non-academic aspects such as self-esteem and motivation in language learning, but lacks clear combination of emotional satisfaction and academic achievement.

\section{Constructivist Theories of Learning}

The essence of constructivist theories of learning lies in the idea that learners should discover and transform complex information on their own if they are to adopt it as their own knowledge and integrate it into their internal schemes. Little's (1994b:431)[19] principle that "all genuinely successful learning is in the end autonomous" reflects the key idea that autonomy in language learning has borrowed from constructivism. And one of the early influences on autonomous learning is from Kelly's (1963)[20] personal construct theory, a belief that "individual learners bring their own systems of constructs to bear on learning tasks." (Benson, 2001: 37)[4] In addition to personal construct theory, Barnes (1976)[21] distinguishes between "school knowledge" and "action knowledge". For Barnes, school knowledge is presented in an abstract form and is someone else's knowledge, so it is easily forgotten. Action knowledge, however, is closely related to the learner's view of the world; it is learners' own knowledge, knowledge which cannot be transmitted from teachers to learners unless active involvement in learning is exercised. As an influential constructivist, Vygotsky emphasizes the importance of social interaction, which makes his theory of learning different from others that employ constructivist principles.

Constructivist theories of learning emphasize the importance of the learner rather than the teacher by encouraging learners to construct their own conceptualizations and to find solutions to problems in the process of learning.

\section{Enlightenments for Further Research}

Oxford (2003)[22] believes that the theoretical framework of learner autonomy in language learning is still far from coherent. These theories are not strong enough to provide a universally accepted model in which autonomous learning can be integrated. Besides, these approaches focus more on learners' emotional condition (especially humanistic psychology) with little consideration to their academic achievement, which is important in assessment of both learner autonomy and teacher autonomy.

Moreover, there is inadequate correlation between these theories that concern the relationships between learner autonomy and language proficiency, and the relationships between learner autonomy and teacher autonomy.

It is widely acknowleged that teacher autonomy plays a key role in the development of learner autonomy. However, few records from these theories are about teacher education programs aiming at developing teacher autonomy, and little is known about the effectiveness of teacher autonomy in fostering learner autonomy. Therefore, in order to improve and enrich these theoretical bases and to promote college English reform in China, empirical studies in Chinese context should be conducted in terms of the following aspects: 1) To what extent does teacher autonomy affect learner autonomy? 2) In what way does teacher autonomy influence learners' language proficiency? 3) What are the relationships between learner autonomy and language proficiency? 


\section{CONCLUSIONS}

The preseant research provides an overview of learner autonomy, teacher autonomy in terms of definitions and then goes on to theoretical bases of these concepts. Based on the previous studies of these concepts and current English language teaching environments in China, this research defines these concepts respectively: Learner autonomy is the capacity to be responsible for one's own learning process, including the capacity to be clear about teaching objectives and one's own goals, to discipline oneself in the process of learning, and to make the best use of English language information; teacher autonomy involves flexibility to cope with both external and internal constraints for the benefit of learning, professional ambitions to exert one's full potential, and realization to develop learner autonomy to achieve lifelong learning. It then moves on to the three theoretical bases of learner autonomy: cognitive learning theories, humanistic psychology, and constructivist theories of learning. Cognitive learning theories stress that learning is an constructive, and cumulative process that is dependent on the mental activities of the learner. Humanistic psychology is a holistic approach which places the individual's inner world at the core of all human development by emphasizing the study of the whole person. Constructivist theories of learning emphasize the importance of the learner rather than the teacher by encouraging learners to construct their own conceptualizations and to find solutions to problems in the process of learning. The present research holds that these concepts and theories, developed in western culture, are not strong enough to provide theoretical bases for the research of learner autonomy in China. It is highly recommended that empirical studies should be done in terms of the relationships between teacher autonomy and learner autonomy in Chinese context.

\section{REFERENCES}

[1] H. Holec, Autonomy in Foreign Language Learning. Oxford: OUP, 1981.

[2] D. Little, “Autonomy in language learning," In I. Gathercole, Ed. Autonomy in language learning, London: CILT, 1990, pp. 7-15.

[3] B. Kenny, "For more autonomy," System, vol. 21, no. 4, pp. 431-442, 1993.

[4] P. Benson, Teaching and researching autonomy in language learning. London: Longman, 2001

[5] L. Dickinson, Self-Instruction in Language Learning. Cambridge: Cambridge University Press, 1987.

[6] L. Dam, "Learner Autonomy in Practice," In Gathercole, I, Ed. Great Britain: Bourne Press, 1990.

[7] D. Gardner, and L. Miller, Eds. Tasks for independent language learning, Alexandria, VA: TESOL, 1996

[8] J. F. Xu, Autonomy in College Foreign Language Learning ---From Theory to Practice. Beijing: China Social Sciences Press, 2007.

[9] D. Tort-Moloney, "Teacher autonomy: A Vygotskian theoretical framework," CLCS Occasional Paper, 48. Dublin: Trinity College, CLCS, 1997.

[10]D. Little, "Leaning as dialogue: The dependence of learner autonomy on teacher autonomy," System, vol. 23, no. 2, pp. 175-181, 1995.

[11]T. E. Lamb, "Finding a voice: Learner autonomy and teacher education in an urban context," In B. Sinclair et al. (Eds.). Learner autonomy, teacher autonomy: Future directions, London: Longman, 2000, pp.118-127.

[12]C. Thavenius, "Teacher autonomy for learner autonomy," In S. Cotterall and D. Crabbe, Eds. Learner autonomy in language learning: Defining the field and effecting change, Frankfurt am Main: Lang, 1999, pp. 163-166.

[13]I. McGrath, “Teacher autonomy," In B. Sinclair, I. McGrath and T. Lamb, Eds. Learner autonomy, teacher autonomy: Future directions, London: Longman, 2000, pp. 100-110.

[14]R. C. Smith, "Starting with ourselves: Teacher-learner autonomy in language learning," In B. Sinclair, I. McGrath and T. Lamb, Eds. Learner Autonomy, teacher Autonomy: Future directions, London: Longman, 2000, pp. 89-99.

[15] Tan Hong, “Teachers' roles in promoting English non-majors'autonomous learning,” Journal of Sichuang International Studies University, no. 3 , pp. 104-105, 2001. 
[16]Huang Jing and Phil Benson, "Teacher Autonomy in Second Language Education," Foreign Languages and Their Teaching, no. 12, pp. 33-37., 2007.

[17]L. Dickinson, “Autonomy and motivation: a literature review," System, vol. 23, no. 2, pp. 165-174, 1995.

[18]G. Ellis, The Study of Second Language Acquisition. Oxford: Oxford University Press, 1994.

[19]D. Little, "Learner autonomy: A theoretical construct and its practical application," Die Neueren Sprachen, vol. 93, no. 5, pp. 430-442, 1994b

[20] G. Kelly, A Theory of Personality. New York: Norton, 1963.

[21]D. Barnes, From communication to curriculum. London: Penguin., 1976

[22] R. L. Oxford, "Language learning styles and strategies: an overview," Learning Styles \& Strategies/Oxford, GALA, 2003. Retrieved October 22, 2009, from http://web.ntpu.edu.tw/ language/workshop/read2.pdf 